\title{
Using Student-Generated Web Comics on Pixton as a Tool for Learning Shakespearean Drama
}

\author{
Niloofar Joneyd, Farhana Diana Deris
}

\begin{abstract}
The study examined the effectiveness of using student-generated web comics on Pixton as a tool for enhancing students' performance in meaning making and learning Shakespearean drama among tertiary level students in university. This study explored students' attitudes towards generating web comics in learning Shakespearean drama. This study was conducted on 35 students who were studying English literature in one of the universities in Iran. This study employed a true experimental of posttest-only control-group research design with a mixed-method approach. The students were chosen based on purposive sampling and were randomly allocated into control group and experimental group. The control group had undergone conventional approach of learning the drama while the experimental group experienced learning through generating web comics in order to learn and construct the meaning of the drama. The instruments used to gather data in this research were post-test and a questionnaire on students' attitudes. The students were given a post-test after learning the Hamlet play written by W. Shakespeare. The questionnaire was distributed to the students in experimental group after conducting the treatment and post-test. Quantitative data derived from the analysis of post-test were tabulated in descriptive statistics and an Independent T-test. Students' answers in post-test were also analysed qualitatively. The results of the questionnaire were coded as numerical scores of frequency and percentage for statistical analysis. The findings of the study revealed that the students who used generating web comics attained a better performance and higher academic achievement in meaning making and learning Shakespearean drama compared to the students who were exposed to conventional learning method. The students also developed strongly positive attitudes towards use of student-generated web comics in learning the drama. This study will help teachers and students to create a new positive environment in the classroom with integration of technology, in which they can feel the enjoyment in effective teaching and learning process of Shakespearean drama.
\end{abstract}

Index Terms: English proficiency, LINUS 2.0 LBI programme, Phonological awareness, Teachers' readiness

\section{INTRODUCTION}

On a global scale, technology has revolutionized and transformed tertiary education. When technology is used effectively, it can become a powerful tool as "curiosity and interest stimulator as well as facilitator in assisting

Revised Manuscript Received on September 22, 2019.

Niloofar Joneyd, School of Education, Universiti Teknologi Malaysia, 81310 UTM Johor Bahru, Johor, Malaysia

Farhana Diana Deris, Language Academy, Faculty of Social Sciences and Humanities, Universiti Teknologi Malaysia, 81310 UTM Johor Bahru, Johor, Malaysia (Email: diana@utm.my) purposeful engagement" (Arnone, et al., 2011). In literature classrooms, technology is generally adopted to foster positive attitudes among students in order to improve their interest and motivation in literary works.

With this in mind, this study aims to identify the benefits of using student-generated web comics in classroom as a tool to enhance their potentials in learning literature specifically Shakespearean drama. This study also aims to look at the students' attitudes towards using Pixton as a web comic generator website in learning Shakespearean dramas in literature classrooms.

Shakespearean dramas are great literature and complex level texts that students need to know in literature classrooms. Students have a hard time finding classic dramas interesting when they are unable to relate to the story (Bright, 2012). Language in Shakespearean dramas is difficult and unfamiliar which has posed problems to students learning the drama (Kermode, 2000). Feeling intimidated or believing that Shakespearean drama is boring is something that can hinder student's ability to learn Shakespeare (Gibson, 2000).

Online learning through websites can engage students in meaning making and learning of Shakespearean dramas in interesting and motivating way in line with learner's need and ability which can be effective. As such, Pixton (http://www.pixton.com/schools/) is a click-and-drag comic development website that can be used to enhance the learning process to create a positive attitude and increase motivation (Engler, et al, 2008; Kilickaya and Krajka, 2012).

Students' generated web comics assist students in taking responsibility for their own learning process because the students formulate their own comics with the purpose of improving their understanding of the drama. Selecting a good medium to teach and learn literature is very important. Therefore, it would be worthwhile to explore the use of web comics in literature classroom in order to promote students' engagement and learning process.

As shown in Figure 1, from reading of past related research, a conceptual framework model was created, which is adopted from a proposed reading model by Russell and Vipond (1985).

In the context of this research, there is a transaction between the text and reader while generating web comics based on the drama, which leads to meaning making and understanding the literary elements of the drama with an emphasis on students' engagement and participation. 
Literature could be very interesting lesson if it is rightly delivered with effective approaches and good materials. Therefore, it is suggested that teacher's employ various strategies and approaches to cope with challenges and find the alternatives to the current traditional methods of teaching and learning in order to motivate students to enjoy learning literature. This project has been conducted to catch up with today's modern technology and make use of it in the field of teaching literature.

\section{LITERATURE REVIEW}

Means (1993), suggested that the use of technology in the classroom could deliver reliable learning prospects to students. Besides, few researchers believed that, the usage of technology in the classroom changes the role and systematizes everyday tasks exclusively, as, it consents students to turn out to be more independent. Students may use peer training, and a teacher's role could be more of a initiator rather than only being a lecturer (Means, 1993; Young, 2008). Hence, it can be said that, technology cannot be considered as an proxy for education all by itself rather it can be used as an integrated instrument with the curriculum to make a difference in education system (Choo, Nawi, \& Abdullah, 2016; Young, 2008).

According to Flintoff (2005), by connecting technology with classic drama, student partakes the chance to study something new that they get to like in advance while moving on to what would be understood as impulsive reading and learning. Hence, this study would focus on student generated web comics as a means of integrating technology with old Shakespearean classic drama.

\section{A. Using Web Comics to Learn Shakespearean Drama}

Starting from the late 90s, comic arose on the internet, which allowed certain noteworthy modifications in the medium (Smith, 2006). Moreover, web comics are considered as actual teaching instrument because they necessitate readers to not only passively accept facts but also actively interrelate with the script and images for meaningful constructs (Horton, 2008). It is necessary for English literature students to read in the complex text which is sometimes very difficult for the students to understand (Cortsen, 2015).

Teachers also sometimes struggle to contextualize older complex text in the literature for example, Shakespearean Drama (McConnell, 2014). Hence, the mixture of old dramas with contemporary web comics would help the students 'to associate thematically with the story plot, characters, period and background, categorizing without the necessity of complex word interpreting expertise (Cortsen, 2015; McConnell, 2014). There are quite a number of online websites, which is used to form student-generated comics, for example, Pixton.

\section{B. Reader Response Theory}

Reader response theory centers mainly on the readers and their connection with the text to make or generate meaning
(Lobo, 2013). Although the literary experience of reading may involve those aspects of learning, the immediate relationship with the reader is the transaction he or she has with the text (Cortsen, 2015). Rosenblatt (2005), personal verses tell us that, visual reading transpires if students have recurrently established that, in impending a text such as, a poem or a novel, can undertake that they are welcome to pay consideration to whatever the verses call to realization. This implies that the visual act of reading is context driven.

In the context of this research, the application of student-generated web comics based on the reader response theory can encourage a meaning seeking process as well as creative atmosphere and interpretation for students in learning literature, particularly drama. Hence, by use of web comics, students can go beyond the reading process and have the freedom to interpret and construct meaning in reality that can further enhance the level of their engagement in learning process.

Moreover, they can materialize the reality in forms of web comics. As mentioned earlier, the visual act of reading is context-driven, which means after the reading process everything will come to play in the mind of the reader; but now this research is allowing students one level further, whereby students are given a tool to project their own background experience as a reader and an individual being in the real life world. Construction of meaning occurs as the reader selects and reflects his/her own background knowledge in terms of the context and re-creates his/her own responses through generating web comics.

\section{RESEARCH METHODOLOGY}

The target population for this study was taken from one of the universities in Iran. A sample size of 35 tertiary level students studying English literature was chosen based on purposive sampling as the respondents in this study. During the treatment, the experimental group was learning Shakespearean drama using student-generated web comics while the control group was learning through the conventional method of learning. A true experimental of posttest-only control-group research design with a convergent parallel mixed-method approach was employed to achieve the purpose of this study (Creswell, 2013). In this study, the data from the post-test are analyzed to investigate students' performance and achievement in meaning making and learning Shakespearean drama by use of student-generated web comics. A set of questionnaire is also distributed to students to determine students' attitudes towards the use of student-generated web comics through Pixton website.

\section{A. Data Analysis}

The data were gathered from the drama post-test and the questionnaire. The post-test score results are computed by descriptive statistics and T-test to evaluate student's performance achievement. answers in the post-test are further analyzed qualitatively 
in essay form.

In the next step in order to identify the student's attitudes toward the use of student-generated web comics, all the data from questionnaire were converted to frequency to express in percentage terms. All descriptive data were analyzed through the statistical package for the social science. (SPSS)

\section{RESEARCH FINDINGS}

\section{A. The impact of student-generated web comics on enhancing student's performance in learning Shakespearean drama}

In the post-test which was based on Hamlet play written by W. Shakespeare, 35 students were divided into two groups; 16 in control group and 19 in the experimental group. Students in the control group were learning the drama using the conventional method while the experimental group experienced learning the drama through generating web comics. The post-test results of experimental and control groups are summarized in Table 1.

Table 1: Post-test results (T-test)

\begin{tabular}{|c|l|}
\hline Groups & \multicolumn{1}{|c|}{ Post-test } \\
\hline $\begin{array}{r}\text { Control Group } \\
\mathrm{N}=16\end{array}$ & $\mathrm{M}=7.3125$ \\
\cline { 2 - 2 } $\begin{array}{r}\mathrm{SD}=2.33006 \\
\mathrm{~N}=19\end{array}$ & $\mathrm{M}=16.3684$ \\
\cline { 2 - 2 } $\begin{array}{r}\text { Experimental } \\
\text { t-test value } \\
\text { Sig. }\end{array}$ & $\mathrm{t}=1.86221$ \\
\cline { 2 - 2 } & $\mathrm{p}<0.000$ \\
\hline
\end{tabular}

B. The impact of student-generated web comics on meaning making and understanding the literary elements of the drama

A variety of responses were given to each question in the test and it showed a pattern of similar types of answers that emerged according to each group. By using the answer key of the test, students' responses to the questions are evaluated and analyzed in terms of depth of their answers; moreover, a comparison is made between experimental and control.

Students' performance in the test showed that the use of web comics as a visual aid rather than the traditional read on text had prepared them better in learning difficult Shakespearean drama. It is apparent that students' answers in experimental group are much more detailed with in depth extra information about the theme, characters and the plot of Hamlet play. Some students in control group were not even able to answer some of the questions and their responses are really short and to the point with no details and even sometimes with wrong answers. The responses of students in experimental group indicates students' profound way of thinking; they produced their answers based on the characters' feelings as they feel themselves being the character throughout the plot in the context of the drama by generating web comics. It also implies that students understand the drama well; they construct meaning and make sense of what has happened during the story in the process of evaluating the characters, providing evidence, describing the conflict in the character and interpreting the main themes.
Students in experimental group could recognize the remarkable quotes, the speaker and the exact context of the quote in the drama; they could accurately identify and analyze the quote as a result of high engagement in the drama while the process of generating web comics. This demonstrated students' ability to identify the important aspects of the play and raise them to the surface of web comics. In general, referring to the answers of control group in the test, it is apparent that their answers are superficial and at the surface level.

As illustrated in the following screenshot (Figure 1) of web comics generated by students, the characters are brought to life through dialogues with modern and easy to understand English language; the selected avatar personifies the characters in web-based comics.

This creative practice had facilitated learning and enabled students to learn drama more efficient using this multimodal visual medium. Hence, the combination of Shakespearean drama with modern web comics would help the students' link thematically with the plot of the story, characters, time and setting, sequencing without needing sophisticated word decoding skills (Cortsen, 2015; McConnell, 2014).

Accordingly, it can be seen that how transferring content from one mode to another could increase engagement. Students feels that generating web comics can "quite literally 'put a human face' on a given subject" (Versaci, 2001) resulting in an intimate, emotional connection between his students and characters of a comic's story. Constructive learning is necessary in a classroom to achieve meaningful learning (Howland, et.al, 2012).

In a nutshell, generating web comics supports students in overcoming the challenges of grasping a difficult text within a shorter time and provides them the tool to go a step further that is by performing it. Thus, appropriate strategy combined with attractive instructional media is strongly recommended to create this condition.

\section{Students' Attitude towards Student-generated Web Comic in Learning Shakespearean drama}

In this study, 19 sets of questionnaire had been distributed to the students in experimental group after being exposed to web comics for learning drama. The data derived from the questionnaire were converted into frequency and percentage for the ease of analysis.

The findings suggested the students have strongly positive attitude towards generating web comics in learning Shakespearean drama that were resulted by several factors, namely teacher's enthusiasm, relaxed and stress-free atmosphere, students' competitive nature, the website's user-friendliness and simplicity of instructions, systematic way of doing homework, self-access learning, knowledge improvement and etc. They find this method to be useful and effective to be implemented in class and claimed that it is more interesting for them to learn drama by generating web comics than conventional method, which is really motivating.

The results also imply that students prefer generating web comics using offline tools. This may be due to difficulties in access to the Internet for some of the students. It was found that, few of the students

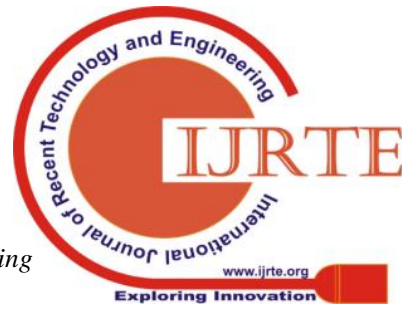




\section{Using Student-Generated Web Comics on Pixton as a Tool for Learning Shakespearean Drama}

thought generating web comics is very time consuming and if there is not internet connection then it is difficult to use it (Azman et al., 2016). Hence, the students desire authoring tools that do not mandate constant Internet connection to efficiently construct educational comics.

Learning barriers or causes of learning difficulties are quite common in an educational setting. There are many strategies to cope with the learning barriers (Coetzee \& Jansen, 2007). Thus, when students develop positive attitudes towards generating web comics, it seems to become an interesting, enjoyable, useful and motivating tool for them in learning drama. Web comic generator websites as 'user friendly' programs can increase students' engagement in the learning process and allow them to explore the world of drama, discover and expand their ideas on learning concepts taught by the teachers. Based on the results, study has demonstrated that students in cooperative and healthy competitive learning environments typically perform better in terms of their creativity, the generation of new ideas and web comics, and how well they transfer what they learn from one form to another.

\section{CONCLUSIONS}

One way for teachers to integrate information technology into their classrooms is through the use of student-generated web comics through web comic generator websites as a tool for learning Shakespearean drama. However, students' attitudes play a great role in the success of materials adapted, developed and integrated into the curriculum and learning process of meaning making of the drama.

Accordingly, the study revealed that there was a significant improvement in terms of students' performance of meaning making and learning Shakespearean drama in post-test after they were exposed to generating web comic strategy. They also developed positive attitudes towards use of web comics in learning the drama. The results of the study suggest that generating web comics leads to greater academic achievement than that of traditional learning approach.

\section{REFERENCES}

1. Arnone, M. P., Small, R. V., Chauncey, S. A., \& McKenna, H. P. (2011) Curiosity, interest and engagement in technology-pervasive learning environments: a new research agenda. Educational Technology Research \& Development 59:181-198. DOI 10.1007/s11423-011-9190-9

2. Azman, F. N., Zaibon, S. B., \& Shiratuddin, N. (2015). Exploring digital comics as an edutainment tool: an overview.

3. Azman, F. N., Zaibon, S. B., \& Shiratuddin, N. (2016). A Study on User's Perception towards Learner-generated Comics. International Review of Management and Marketing, 6(8S).

4. Azman, F. N. Z., Syamsul Bahrin ; Norshuhada Shiratuddin. (2016). A Study on User's Perception towards Learner-generated Comics. International Review of Management and Marketing, Vol 6. Adapted from Coetzee, M. \& Jansen, C. (2007).

5. Bright, Amy.(2012). "Writing Homer, Reading Riordan: Intertextual Study in Contemporary Adolescent Literature." The Journal of Children's Literature. 37.1 (2011): 38-48. ERIC. Web. 21 Oct.

6. Cortsen, R. P. (2015). Teaching with Comics. Oulu Comics Magazine.

7. Engler, S., Christopher, H. \& Payne, S. (2008). Computer-produced comics as a means of summarising academic readings in EAP programs. International Journal of Pedagogies and Learning, 4, 4, 19-33.

8. Flintoff, K. (2005). Drama and technology: Teacher attitudes and perceptions.

9. Choo, Y. B., Nawi, A. M., \& Abdullah, T. (2016). Facebook: A Tool to Engage Students in MEeaning Making OF Shakespearean drama. Man In India, 96(6), 1891-1902.
10. Creswell, J. W. (2013). Research design: Qualitative, quantitative, and mixed methods approaches. Sage publications.

11. Gibson, R. (2000). Teaching Shakespeare. New York: Cambridge University Press.

12. Horton, S. (2008). Webcomics 2.0: An Insider's Guide to Writing, Drawing, and Promoting Your Own Webcomics: Nelson Education.

13. Hunt, Russell A. and Douglas Vipond (1985), 'Crash testing a transactional model of literary reading', Reader, 14,pp.23_39.

14. Howland, Jane, David Jonassen, and Rose Marra. Meaning ful Learning with Technology. Upper Saddle River: Pearson, 2012. Prinišpi]

15. Kermode, F. (2000). Shakespeare's language. New York: Farrar, Straus \& Giroux

16. Kilickaya, F. and Krajka, J. (2012) 'Can the use of web-based comic strip creation tool facilitate EFL learners' grammar and sentence writing?', British Journal of Educational Technology, Vol. 43, No. 6, pp. 161-165.

17. Krech, D.; Crutchfield, R.S. (1948). Theory and Problems of Social Psychology; McGraw-Hill: New York, NY, USA. isẸp:

18. Lobo, A. G. (2013). Reader-Response Theory: A Path Towards Wolfgang Iser (La teoría de la recepción: una ruta hacia Wolfgang Iser). Letras, 2(54), 13-30

19. McConnell, R. H. (2014). Graphic Drama: Reading Shakespeare in the Comics Medium. The University of Western Ontario.

20. Means, B. (1993). Using technology to support education reform: ERIC.

21. Megawati, F., \& Anugerahwati, M. (2012). Comic Strips: a study on the teaching of writing narrative texts to Indonesian EFL students. Teflin Journal, 23(2), 183

22. Morrison, T. G., Bryan, G., \& Chilcoat, G. W. (2002). Using student-generated comic books in the classroom. Journal of Adolescent \& Adult Literacy, 45(8), 758-767.

23. Rosenblatt, L. M. (1982). The literary transaction: Evocation and response. Theory into practice, 21(4), 268-277.

24. Rosenblatt, L. M. (2005). Literature--SOS! Voices from the Middle, 12(3), 34-38.

25. Rostika, D., \& Windayana, H. (2016). The Use of Comic Strip Worksheet In Enhancing Elementary School Students' Learning Achievement in Mathematic.

26. Smith, A. (2006). Teaching with Comics.

27. Versaci, R. (2001). How comic books can change the way our students see literature: One teacher's perspective. English Journal, 91 (2), 61-67.

28. Young, R. (2008). Using technology tools in the public school classroom. University of Wisconsin: Unpublished Master's Thesis.

29. Yunus, M. M., Salehi, H., Tarmizi, A., Syed, S., \& Balaraman, S. (2011). Using digital comics in teaching ESL writing. Research Journal of Applied Sciences, Engineering and Technology, 4(18), 3462-3469.

\section{AUTHORS PROFILE}

Alsaif Sarah Ali M, Studying as student at School of Education, Faculty of Social Sciences and Humanities, Universiti Teknologi Malaysia, 81310 UTM Johor Bahru, Johor, Malaysia

Dr. Farhana Diana Deris, is a Senior Lecturer at the Language Academy, Universiti Teknologi Malaysia (UTM). She is currently the Manager of Partnership at UTM International. 